\title{
Experimental analysis of vertical axis wind turbine active pitch control system with Permanent Magnet Synchronous Motor using MATLAB Simulink tools
}

\author{
Tomas Komass \\ Institute of Energetic, \\ Latvia University of Agriculture, \\ J. Cakstes bulvaris 5 , \\ LV-3001 Jelgava, Latvia \\ E-mail tf11198@llu.lv
}

\begin{abstract}
Efficient vertical axis wind turbine (VAWT) technology is a key topic for the future wind energy market. At the moment, VAWTs are seldom used for electricity production. The development of new technologies for building a new generation of VAWTs, which will be more efficient, user-friendly, and with very low noise pollution levels is the target for many researchers. The goal of this research was to analyse an active pitch control system in an experimental setting through construction of an active pitch control system test bench using a Permanent Magnet Synchronous Motor (PMSM) and to develop new testing programmes for analytical system performance tests. The current commercial turbines do not carry an active pitch system for a VAWT; however, the concept of an active turbine blade pitching opens new opportunities for boosting the efficiency, safety, and user-friendliness of VAWTs. The research consists of the mathematical model and control system operating in a simulation environment in a closed loop with the test bench setup consisting of an active pitch control system. By applying a specially developed VAWT simulation model implemented in MATLAB Simulink, an active pitch system was tested and analysed under various conditions, which were as close as possible to the real-world operating conditions. The results of the testing and analysis show that an active pitch system using the PMSM can be very efficient and fast-operating. An active pitch system is able to work on the needed conditions by using the PMSM. Analysis shows that while using the PMSM for a turbine active pitch system, certain conditions should be taken into account in order to achieve the best results and to reduce costs. Full and effective use of active pitch system components can improve VAWT performance.
\end{abstract}

Key words: VAWT, pitch control, PMSM, wind turbine, MATLAB

\section{INTRODUCTION}

Renewable power resources as one of the world economy sectors and their effective and efficient use play a key role in the development of modern society. The very aspect of energy resource renewability is the main incentive for developing this kind of energy resources. Indeed, long-term experience shows that renewable resources pos- sess an extremely high potential, which is recoverable, yet their use is far from being abundant [1]. The global scientific research community is currently focused on how to make the equipment operate at a higher level of efficiency.

A lot of research has been done, which proved that for the present no first-best solution for vertical axis wind turbines (VAWTs) has been found yet, because despite high benefits their weakest 
point still is low efficiency [2]. The power acquired from a low-quality and low-efficiency wind turbines quite frequently receives a negative interpretation; therefore, a demand for the high quality wind turbines in the world stays high while supply is too low.

An improvement means financial or some other benefit; however, as long as the threshold for the acquired power in terms of quality and quantity is reached, people tend to perceive other aspects as those of minor importance. Nevertheless, the work on the new solutions may lead to simultaneous improvements in many other aspects of one specific problem. Vertical axis wind turbines are generally viewed as passive turbines with the blades of some particular shape; however, as is well known, the wind turbines of horizontal axis type possess one large benefit - active operation [3], which means that if a vertical turbine is to be converted from a passive element into an active one, it would yield actual benefits.

Adjustment of the active blade pitch angle of vertical axis wind turbines is a possible key solution, which would ultimately result in a much more efficient vertical axis wind turbine meaning lots of benefits for the global community. Analytical researches prove that a wind turbine may become a $14 \%$ more efficient compared to the nominal wind turbine yield; however, if we look at a range of commercially available items, we see that the technology based on adjustable blade pitch angles has not yet reached a reasonably high degree of commercialisation and thus is not very common in the wind turbines available for routine use [4].

Following information on the recent developments in this market segment, the authors felt an urge to conduct a real-life experiment involving a system for adjusting the blade pitch angles, which would provide an opportunity to analyse the application and significance of such system as well as to identify its drawbacks or formulate some specific requirements with respect to the design solution or control system of the turbine.

\section{MATERIALS AND METHODS}

Topologically, an active blade adjustment system is similar for all blades and systematically the overall structure remains the same whatever electric motor drive type is used - with one central control unit, which calculates the necessary blade pitch angle adjustment as a function of operational (technological) parameters, or each drive motor having its own control unit directly responsible for electric motor settings [5]. The most frequently used drive types are:

- servo motors,

- DC step motors.

The operation of each blade control system is based on the performance of the pitch angle task by following up and checking the task completion via electronic feed-back. Electronic angle measurement is done by:

- impulse TTL encoder,

- absolute SSI encoder,

- SIN/COS encoder,

- resolvers.

The need for high-speed operation of the active blade control system depends on the wind turbine itself. Given the geometrical dimensions of the turbine and the tip speed ratio (TSR), it becomes possible to obtain the angular speed of the wind turbine rotor calculated as a function of the wind velocity [6].

A VAWT with the Darrieus H-type rotor diameter of $10 \mathrm{~m}$ and the blade length of $10 \mathrm{~m}$ was selected for testing (Fig. 1). The turbine blade profile is NACA0018 and the tip speed ratio $\mathrm{TSR}=2.5$. Assuming that for the test purpose the turbine $R=5 \mathrm{~m}$, then spin velocity $n=60 \mathrm{rpm}$ given the tip speed ratio $\lambda=2.5$ and wind speed (velocity) $V=12 \mathrm{~m} \cdot \mathrm{s}^{-1}$. It means that the turbine tests should be run to the maximum speed in order to check the servo system capabilities to perform the task by ensuring the maximum speed.

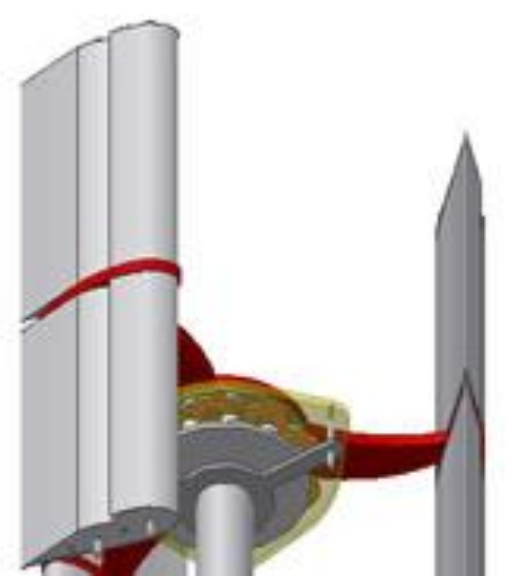

Fig. 1. Darrieus H-type rotor (personal archive) 
While the rotor of the wind turbine rotates round the rotation centre from $0 . .360^{\circ}$, the active blade control system should perform a new rotation angle task at each rotation angle. In this manner it follows the optimal blade angle. In parallel with that, not only the rotation angle but also the direction of the wind flow against the rotor serve as the active blade control indicators. For the control system, it is important to measure the direction of the wind flow, upon which the active blade control start and homing centre would be dependent, accordingly. For testing purposes, we assume that the wind flow direction and velocity are constant against the rotor position $\theta=0^{\circ}$.

Based on the data obtained during the previous series of research testing the efficiency of the VAWT blade pitch angle, we have drawn a chart in which the blade pitch angle is a function of the angle of rotation of the rotor. It means that using this relationship it is necessary to arrange the data in the form of a table in the MAT$\mathrm{LAB}$ environment, where the incoming signal will be the angle of rotation of the rotor $\theta$, while the outcoming signal will be the calculated blade pitch angle $\alpha$ (Fig. 2).
For the test bench to operate in the same manner as a real-life equipment, it is important to take into account the real-life load upon the servo system, which means that the servo system, when adjusting the blade pitch angle, is being subject to extra load caused by rotor inertia and aerodynamics, which is changing throughout the process depending on the total relationship of the blade pitch angle against the wind flow vector.

In the course of analysis of the NACA0018 blade profile, physical parameters were obtained, which means that if the polycarbonate materials are used, the blade mass is approximately $139.2 \mathrm{~kg}$ and the offset of its centre of gravity (COG) from the blade rotation axis is $83.79 \mathrm{~mm}$ along the horizontal axis $\mathrm{X}$, which represents a central line of the blade chord.

The test bench is comprised of three core components and needs to have the physics of the momentum of inertia of a real blade replaced. The moving mass of the test bench is $10.257 \mathrm{~kg}$, which should be located at a $311 \mathrm{~mm}$ distance from the rotation axis centre.

The control system components are replaced by a simplified task sending system, which uses a PC

Table 1. Test bench equipment

\begin{tabular}{cccc}
\hline No. & Equipment & Model & Manufacturer \\
\hline 1 & Worm gearbox & CHM 040 71B5 7.5 & Chiaravalli \\
\hline 2 & Servo motor & MS4612N4008E43F10 & ABB Oy \\
\hline 3 & Servo drive & ACSM1-04AM-03A0-4+L516 & ABB Oy \\
\hline 4 & Encoder interface & FEN-21 & ABB Oy \\
\hline 5 & Signal converter & NI-6008 & National Instruments \\
\hline 6 & Simulation PC & HP Nx6453 & Hewlett Packard \\
\hline
\end{tabular}

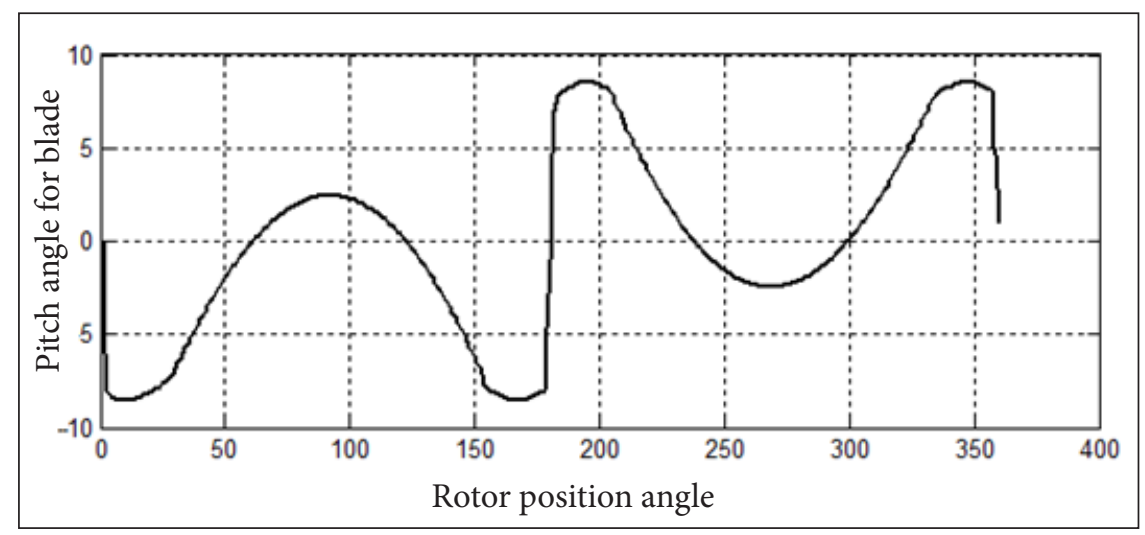

Fig. 2. Blade pitch control angle as a function of the angle of rotation of the rotor [7] 
with the MATLAB Simulink software and a NI manufactured signalling unit NI-6008, which with the help of an analogue signal $0-5 \mathrm{~V} \mathrm{DC}$ will set the required angle task in the servo regulator.

The units of the equipment are mechanically and electrically connected to each other, their operation is checked. The connection diagram shows the layout of the locking-up of signals. The servo system is hooked up to $3 \sim 400$ VAC. The servo motor interface is connected to the servo regulator power outlet, and the signal measuring the angle of pitch of the servo motor is connected to the servo regulator module FEN-21 (Fig. 3).

The internal algorithm of the servo system operates in a "Synchron" mode, meaning that upon receipt of the position task by the servo system control unit, the position is taken automatically based on pre-set internal operation parameters. Given a high speed of the control process, it is a prime necessity to set the parameters of the servo regulator in a way to ensure the highest possible servo motor operation speed. This adjustment is connected to adjustment of two main chains - the speed adjustment chain and the position adjustment chain.

Industrial solutions worldwide are using the PMSM with a high working torque in a wide rotation speed range. The advantage of using the PMSM in the blade angle control is the ability to work in a wide rotation speed range and achieve the same nominal working torque. That means the system can be designed with or without the gearbox for angle reduction. Using the direct drive system is possible, but the difference and advantages of the direct drive system will be analysed over the experimental tests and results.

In order to ensure the test bench operation under real-life wind conditions with the real-life performance of signals, a testing programme should be developed, which would assist in turbine simulation at a range of wind velocities and then record the obtained results for subsequent graphical analysis. The test bench programme has been developed in the MATLAB Simulink environment, and by setting the simulation wind velocity the turbine operation was simulated for $60 \mathrm{~s}$.

A mechanical frame which uses a gearless direct drive provides an opportunity for an effective blade pitch angle adjustment to higher precision. Let us assume that the angle of pitch of the motor is decreased to the minimum and it needs to slew to the same extent as the blade would slew. Depending on motion reference distance, the final motion time of the servo system varied.

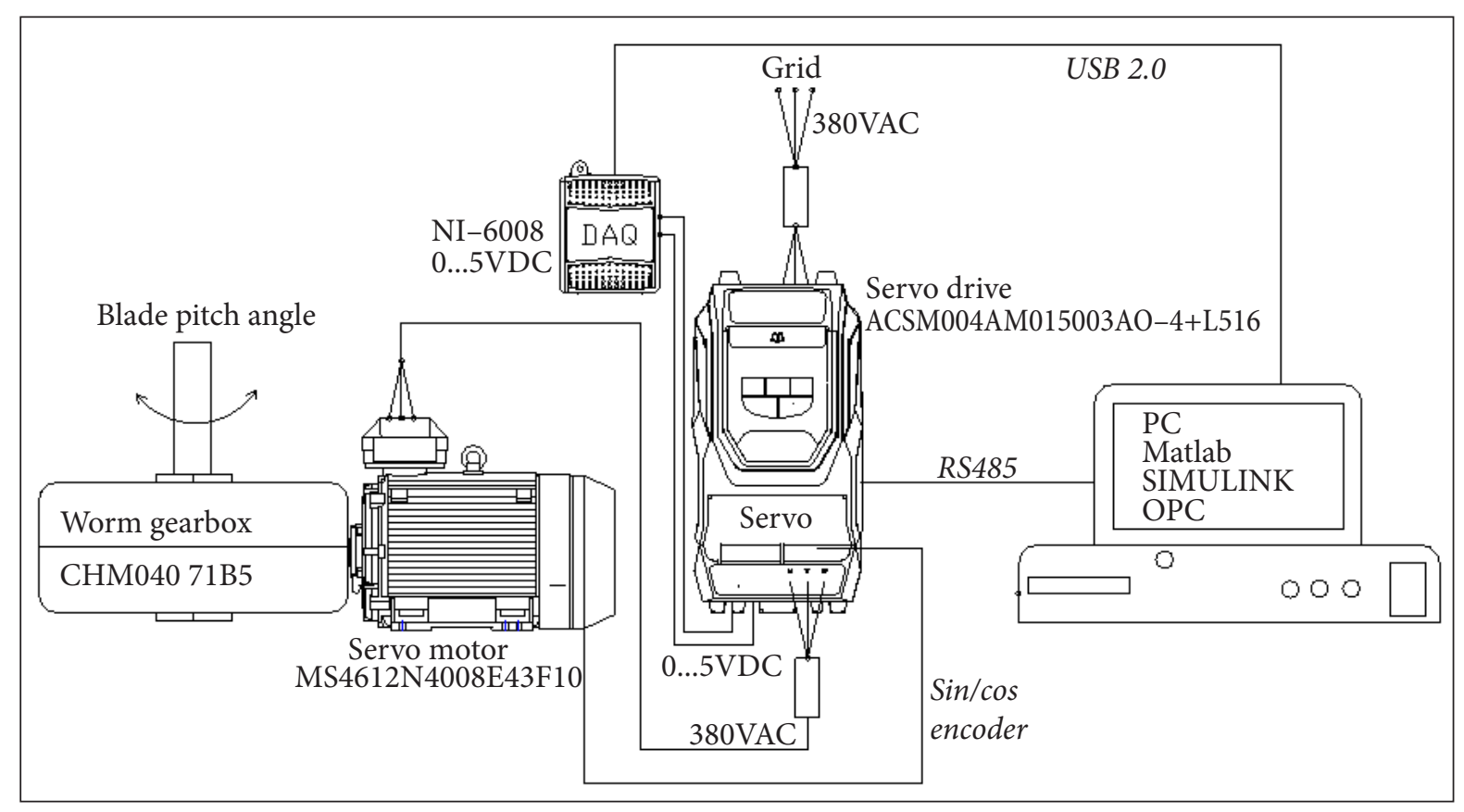

Fig. 3. The test bench servo system structure diagram 
The servo regulator runs 3 main process control algorithms, which are interrelated. There are performance algorithms for the rotational torque control, rotation velocity control, and servo system position control (Fig. 4).

Figure 4 presents a manufacturer pre-set internal speed performance algorithm with the attached parameters, which are experimentally verifiable and can be input in the system. The algorithm shows that the output value of the position algorithm is a speed task to the speed control algorithm, which subsequently shapes the necessary torque task with the help of the parameters set by PID (Fig. 5).

The connection of a chain of three algorithms requires fair adjustment of the parameters. The adjustment process should be started with the control algorithm that is the last in the row, which is the torque. When the torque control algorithm is properly adjusted, one should move on to adjusting the parameters of the speed control algorithm, the last being adjustment of the position control algorithm parameters.

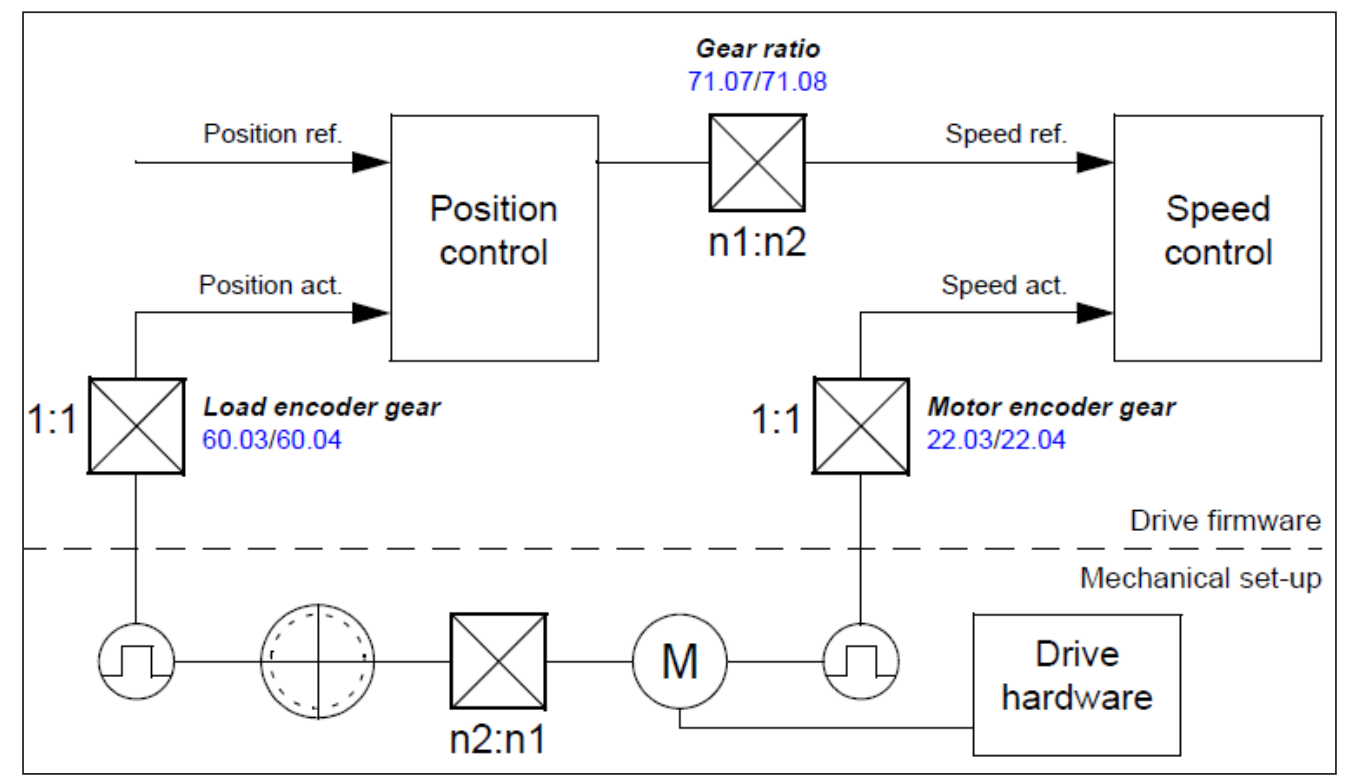

Fig. 4. Structure of the servo system position control algorithm

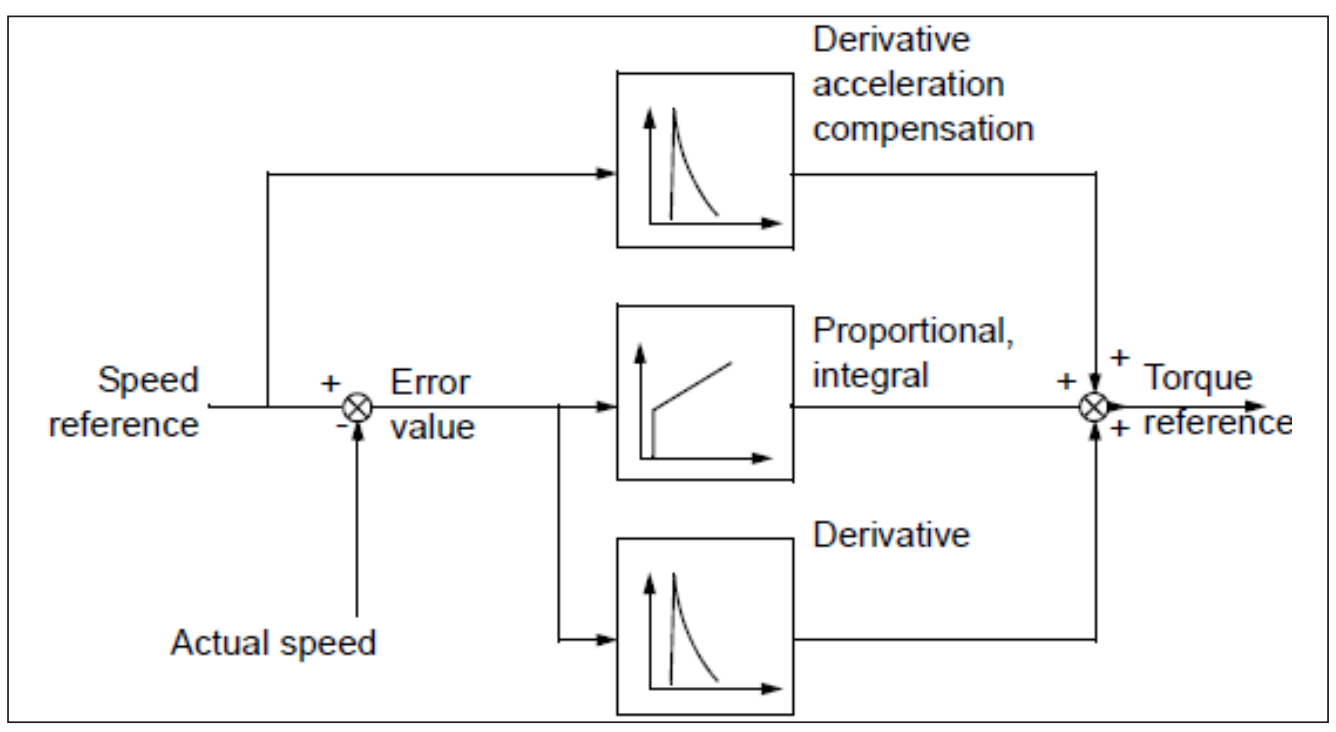

Fig. 5. Structure of the servo system position control algorithm 


\section{RESULTS AND DISCUSSIONS}

The process of testing includes obtainment of experimental results reflecting the real-life servo system operation features, by using these for adjustment of the blade pitch angle. The ACSM1 servo motor controller internal groups have the default factory settings as is common for any new equipment. For system adjustment, a special testing programme was created in the MATLAB Simulink environment, which records the necessary tasks in the ACSM1servo controller.
The quality of the servo controller set parameters is analysed with the help of DRIVE STUDIO V1.6 data recording functions by repeating the task several times. The recorded data were fully processed with the help of an algorithm compiled by the MATLAB Editor, where the data output provided the complete information about system operation at the measurements taken. Figures 6 and 7 show the processed adjustment data both at the signal front and fall when measuring the servo system speed and position tasks.

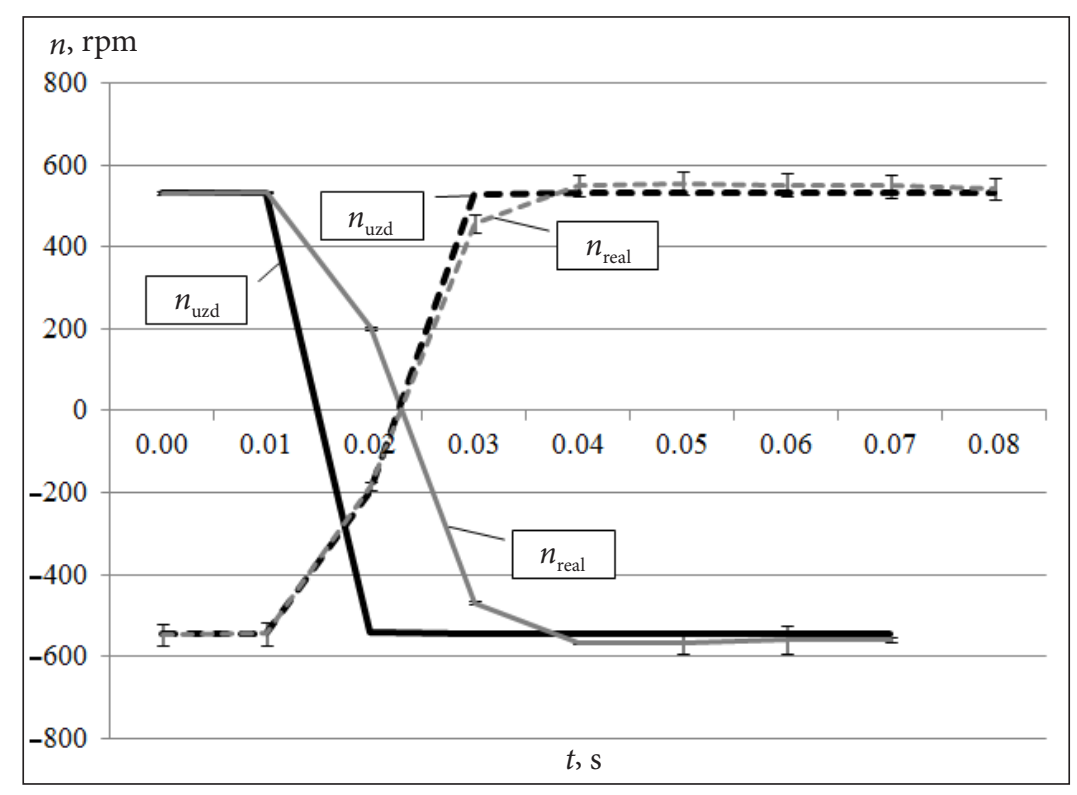

Fig. 6. Speed adjustment experimental results

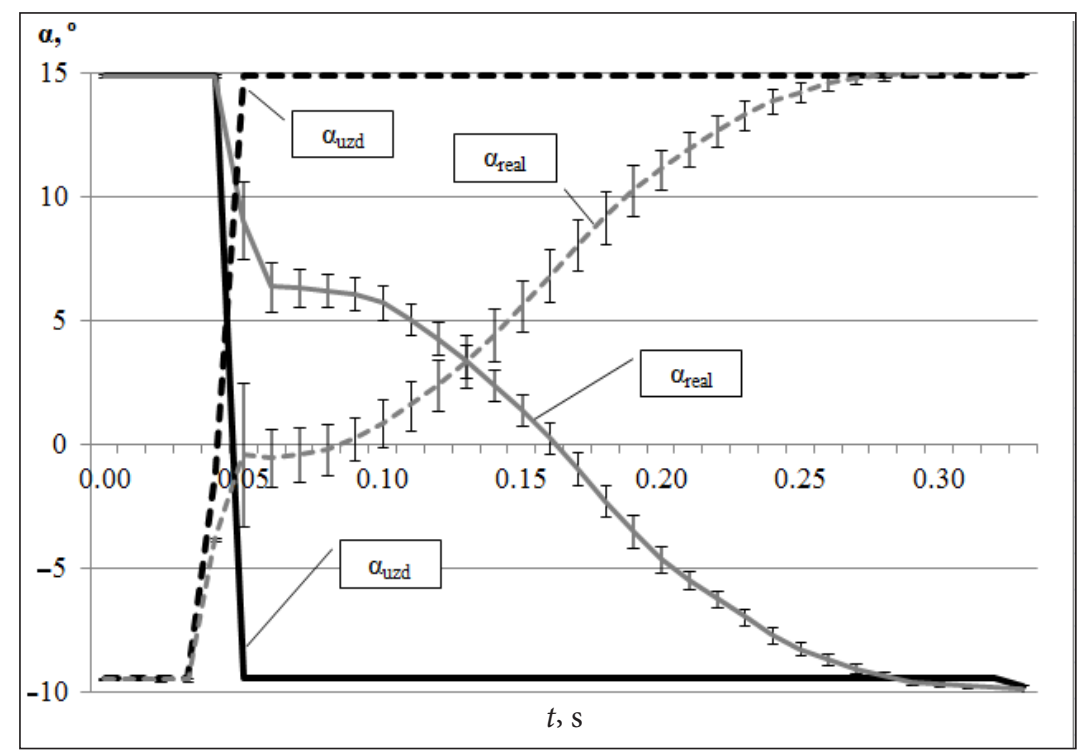

Fig. 7. Experimental results of position adjustment 
In the process of adjusting the ACSM1 parameters, it is necessary to align the torque, speed and position control parameters. For the system to operate at the highest possible speed, it is necessary to fine-tune the torque control algorithm, in this way achieving a more aggressive task performance. After having adjusted the torque, it is necessary to check the performance of the task for the system speed control algorithm by fine-tuning the control parameters until a much quicker and steadier speed task performance is achieved.

Figure 8 shows characteristic curves of the adjusted servo regulator. Upon completion of parameterisation of the torque and speed algorithms, the next task was to perform parameterisation of the position control system algorithm for achieving faster task performance and high system performance stability.

The programme developed in the MATLAB Simulink environment simulates a real-life turbine rotation, and depending on the angle of pitch of the turbine rotor the outgoing signal $\alpha_{u z d}$ is recorded in the servo system controller, which performs the positioning task. The main goal of the experiment is to analyse the capability of the real-life equipment to track the set pitch angle task $-a_{\text {uzd }}$.

Experimental research was carried out in two modes - the servo motor operating with and without a gear, that is, operating with a reduction coefficient $i=1$ and $i=7.5$, respectively. Given that the maximum rotation speed of the test turbine is $60 \mathrm{rpm}$, the servo system experiments will be performed at two turbine rotation speeds: $n=60 \mathrm{rpm}$ and $n=30 \mathrm{rpm}$.

The accuracy and speed of system operation are very high and the performed task is consistent with the given one at the speed value of both $n=30 \mathrm{rpm}$ and $n=60 \mathrm{rpm}$ (Fig. 9). A high accuracy of tracking and low impact torque $T_{m}$ are explained by operation under no load. The torque $T_{m}$ does not reach the maximum level of $10 \%$ of the nominal motor torque.

When under load, the system without a reduction gear is capable to track the task with less accuracy, which is demonstrated by the measurement results (Fig. 10). When under load and at large $\Delta \alpha_{\mathrm{uzd}}$, system capacity is not sufficient for a relatively fast task tracking, which is demonstrated by these deviations at the highest and lowest segments of the curves. Task performance at a higher speed of rotation is least accurate, which may be the proof that the servo motor capacity is insufficient for such high-speed task performance.

Graphical presentation of the results of the experiment with the reduction gear $i=7.5$ shows that in case of a 7.5 times higher displacement at the fastest moments of the task $\Delta \alpha_{\text {udd' }}$, the motor is unable to perform the task; however, at a later stage the task is performed with high accuracy. Yet, at the speed of rotation of $60 \mathrm{rpm}$, the task is not performed within the time period from $t=8 \mathrm{~ms}$ to $t=50 \mathrm{~ms}$, while over the period from $t=50 \mathrm{~ms}$ to $t=100 \mathrm{~ms}$ the task is

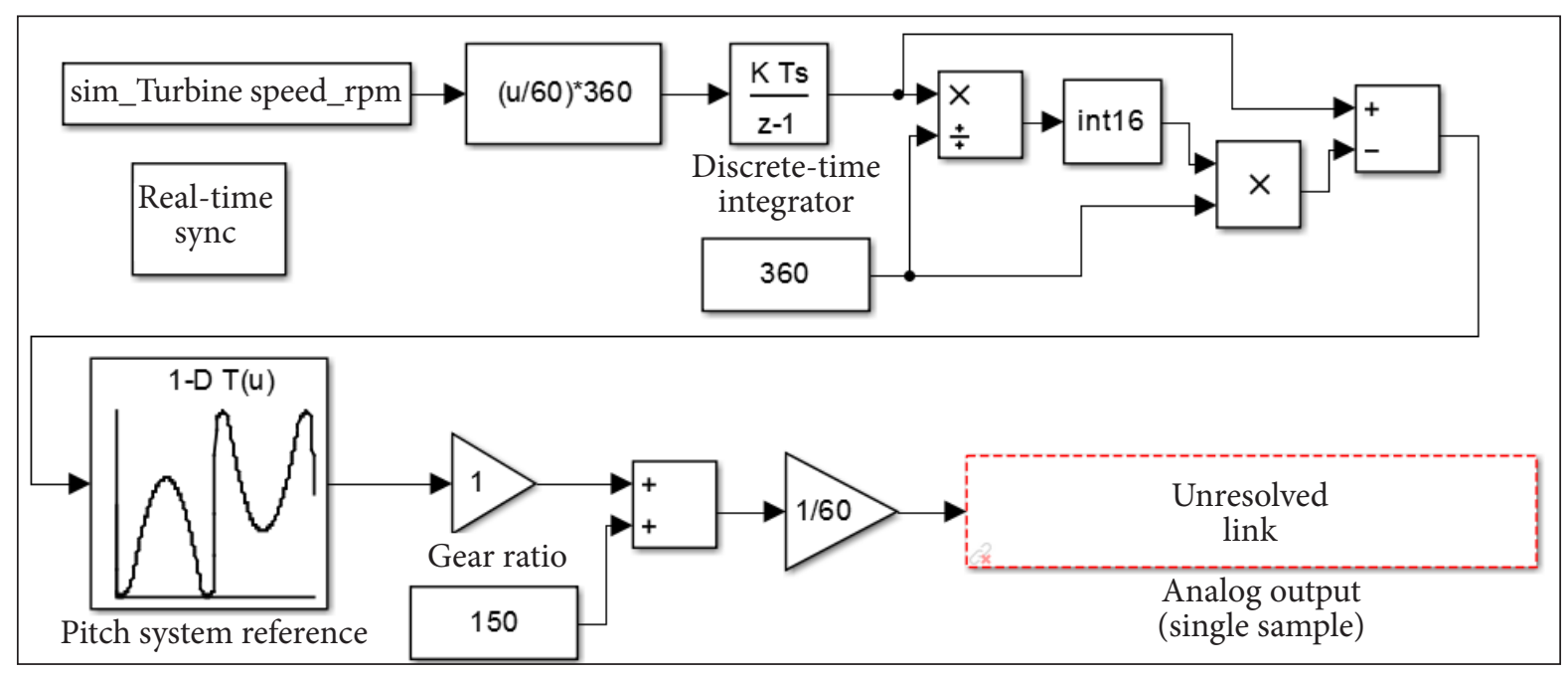

Fig. 8. Servo system test programme in MATLAB Simulink environment 

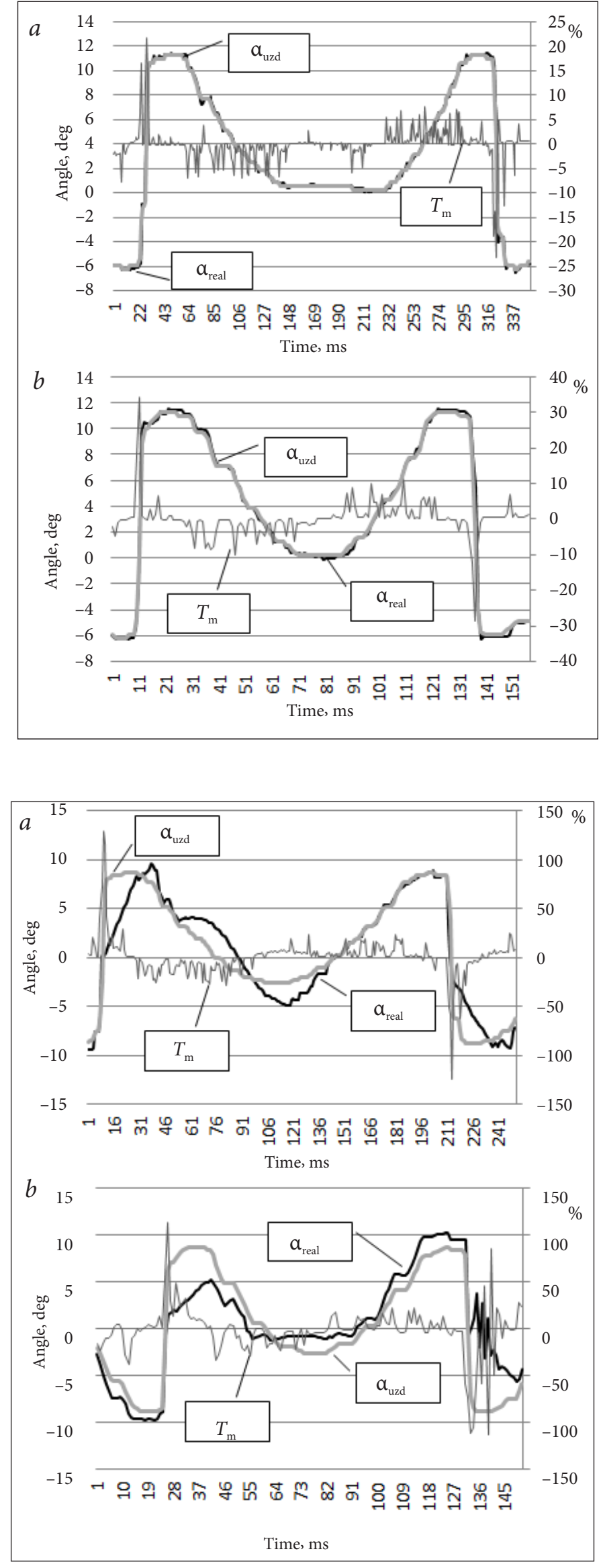

Fig. 9. System test during no load operation without the reduction gear $(i=1):(a) n=30 \mathrm{rpm},(b)$ $n=60 \mathrm{rpm}$

Fig. 10. System test with load operation $(i=1):(a)$ $n=30 \mathrm{rpm},(b) n=60 \mathrm{rpm}$ 
performed with high accuracy. The explanation is small $\Delta \alpha_{u z d}$.

Experimental results show the functionally inadequate operation of the system and the failure to perform accurate task tracking. Even at small values of $\Delta \alpha_{\text {uzd }}$ the task is not performed, while at larger $\Delta \alpha_{\mathrm{uzd}}$ the task performance fails to achieve the required values. When the system operates at a high gear and under high load, it experiences difficulty with performing the set task at an appropriate speed, because at $30 \mathrm{rpm}$ the set point is being adjusted for $330 \mathrm{~ms}$, while at the highest speed of rotation the task cycle is just $180 \mathrm{~ms}$.

The direct drive connected system in experiments showed better results in the speed performance, but the system in direct drive mode can be less stable in a variant loading process what requires adaptive control system parametrisation. With a gearbox, the system is less fast but more sta- ble. The system working with a gearbox can provide a better mechanical performance and work a longer period without additional maintenance.

For a system with active blade adjustment using PMSM parameterisation of servo controller is an important factor, which ensures maximum effect and accuracy of system operation. However, experiments demonstrate that using a servo controller with the same settings proves impossible for the operation under different loads. In case of a higher load, the controller setting values should be increased thus achieving a higher rate of increase of the torque per unit of time. At the same time though, with higher controller setting values it becomes impossible to operate at smaller loads. It means that it is necessary to ensure adaptive self-adjustment of the controller parameters, which would mean the system seamless operation under any load conditions.

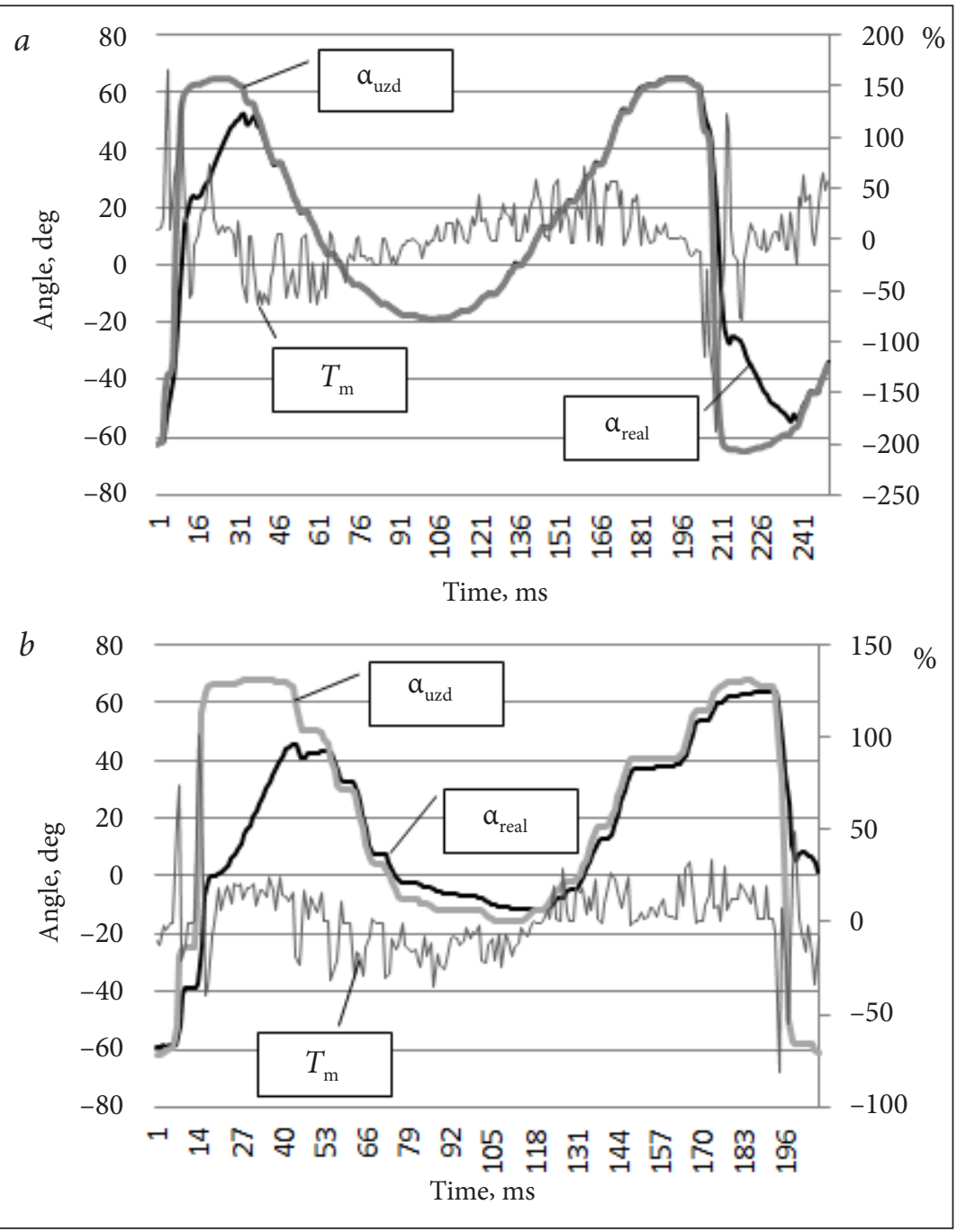

Fig. 11. System test at no load and with reduction gear $(i=7.5)$ : $(a)$ $n=30 \mathrm{rpm},(b) n=60 \mathrm{rpm}$ 


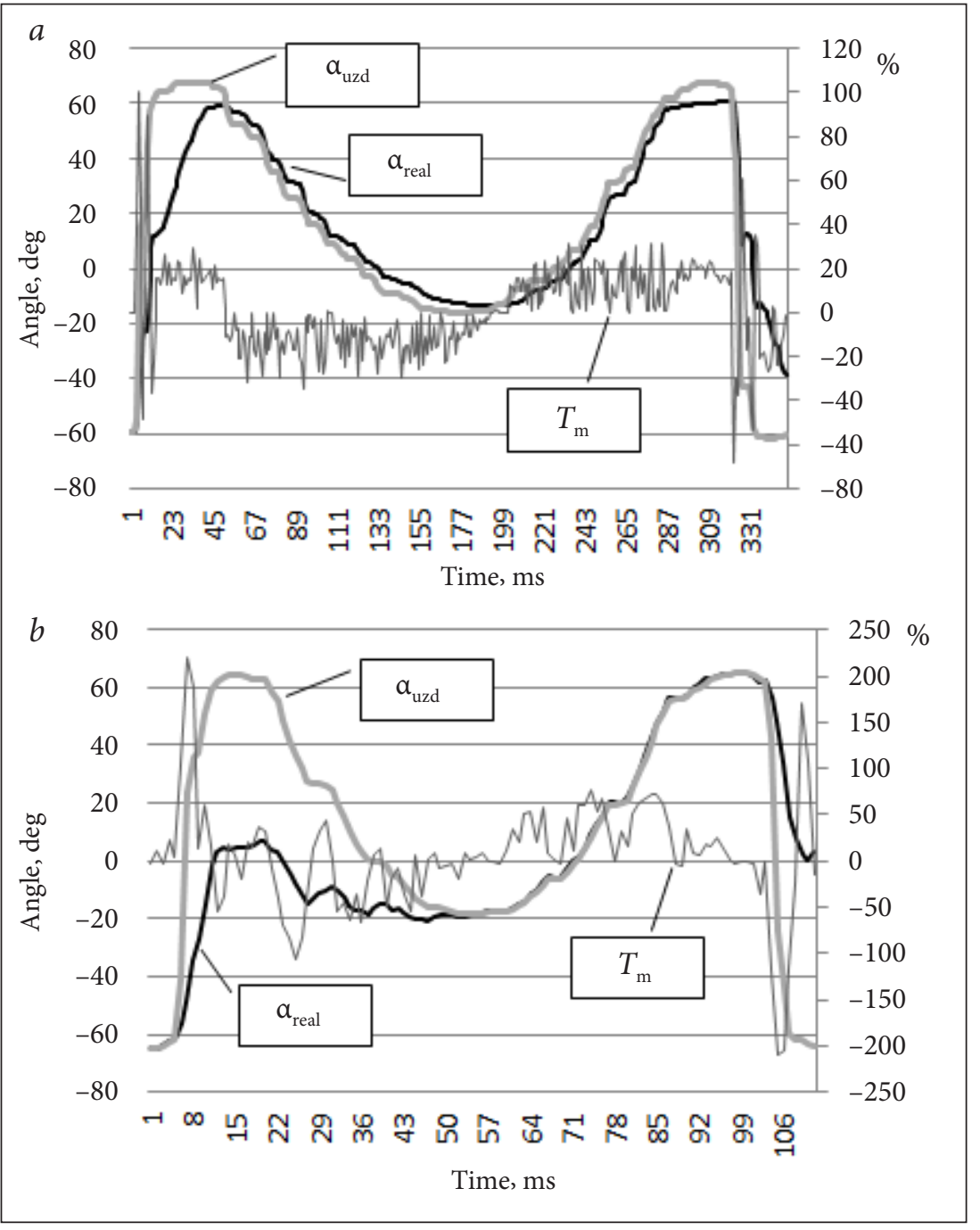

Fig. 12. System test at load $(i=7.5):(a) n=30 \mathrm{rpm},(b)$ $n=60 \mathrm{rpm}$

\section{CONCLUSIONS}

1. Experimental results show that the PMSM may be used in vertical axis wind turbines with an active blade adjustment system, which is proved by high quality and accuracy of performance of the task - adjustment of the blade angle of pitch.

2. For boosting the speed of the controlling system, a direct drive PMSM with a through-going rotor shaft without a reduction gear should be used, in this way ensuring gear $i=1$ and highspeed operation, which is evidenced by the experimental results.

3. The drawback of using a direct gear is higher requirements to control system adjustment quality and possible adaptation at load variation because the system may become less stable in case of change of various physical parameters.
4. High quality of the control system means high quality of the obtained results. The experiments showed that an easily adjustable and adaptable system is able to improve the quality of the output signal. Self-adjustment is the primary condition for using the control system in performance of such technical assignment.

5. Experimental results show system work difference in work without load and with gear ratio $i=1$ where the motor position error is less than $\pm 1 \mathrm{deg}$, but with gear ratio $i=7.5$ the servo motor position error is maximum $20 \mathrm{deg}$ in the period of high $\Delta \alpha_{\mathrm{uzd}}=60$ deg in time of $16 \mathrm{~ms}$. At the same time with the turbine rotor speed of $60 \mathrm{rpm}$ and the pitch system gear ratio $i=7.5$, the error reaches $60 \mathrm{deg}$, which shows that the system cannot reach the needed performance of the process.

6. The measured results show that the blade active pitch system with gear ratio $i=1$ used with 
nominal load is less stable reaching position error $\pm 3 \mathrm{deg}$, and compared with system work without load and $i=1$, the system tuned values should be retuned for the load changes in the active blade.

7. The blade pitch system test results with gearbox gear ratio $i=7.5$ show more accurate work results and system stability with the servo motor position maximum error of $50 \mathrm{deg}$ in high reference point changes where in $8 \mathrm{~ms}$ reference of angle $\alpha_{\mathrm{uzd}}$ changes from $-60 \mathrm{deg}$ to $+60 \mathrm{deg}$. In the same conditions, but with the turbine rotor rotation speed of $60 \mathrm{rpm}$ the pitch system error in the same graph par error reaches $65 \mathrm{deg}$. That can be explained by a too small power servo motor, because the motor torque is over limits, which means that the motor PID is reaching the limits, but the motor torque is not enough to reach the needed speed.

8. Due to the simulation process, the results showed that the servo system cannot work with one set of tuned values as the actual forces and perturbations vary in time and the time constant of the object transfer process varies in time, which makes the pitch servo system not able to work with in the same setting over all wind turbine working wind speed ranges.

Received 5 April 2016 Accepted 15 May 2016

\section{References}

1. Ferone C., Robinson M., Shi Y., Vishwakarma V. A control policy for maximizing the power output of variable pitch VAWTs and reducing fluctuations in power with a battery. College of
Engineering Research Symposium, 5 April 2012, Pennsylvania State University, University Park.

2. Aslam Bhutta M. M., Hayat N., Farooq A. U., Ali Z., Sh. Rehan J., Zahid H. Vertical axis wind turbine - A review of various configurations and design techniques. Journal Elsevier - Renewable and Sustainable Energy. 2012. P. 1926-1939.

3. Khalid S. S., Liang Z., Qi-Hu S., Xue-Wei Z. Difference between fixed and variable pitch vertical axis tidal turbine-ising CFD analysis in CFX. Research Journal of Applied Sciences, Engineering and Technology. 2013. Vol. 1. P. 319-325.

4. Komass T. Mathematical modelling and calculation of vertical axis wind turbine pitch system using Matlab tools. AASCIT Journal of Energy. 2015. http://www.aascit.org/journal/energy

5. Khajuria S., Kaur J. Implementation of pitch control of wind turbine using Simulink (Matlab) International Journal of Advanced Research in Computer Engineering \& Technology, 2012. Vol. 1. Issue 4. P. 196-200.

6. Miau J. J., Liang S. Y., Yu R. M., Hu C. C., Leu T. S., Cheng J. C., Chen S. J. Design and test of a vertical-axis wind turbine with pitch control. Applied Mechanics and Materials. 2012. Vol. 225. P. 338-343.

7. Islam M., Ting D. S.-K., Fartaj A. Aerodynamic models for Darrieus-type straight-bladed vertical axis wind turbines. Renewable and Sustainable Energy. 2008. P. 1087-1109.

8. Komass T. VAWT blade aerodynamic torque analysis with the help of Matlab tools. American Journal of Energy and Power Engineering. 2015. http://www.aascit.org/journal/ajepe 
Tomas Komass

VERTIKALIOS AŠIES VĖJO ELEKTRINĖS AKTYVIOS MENČIŲ POSŪKIO

VALDYMO SISTEMOS SU NUOLATINIŲ MAGNETŲ SINCHRONINIU VARIKLIU EKSPERIMENTINIS TYRIMAS NAUDOJANT MATLAB SIMULINK İRANKI

\section{Santrauka}

Efektyvios vertikalios ašies vejo elektrinès technologijos yra svarbios vejjo energetikos ateities rinkai. Šiuo metu jos retai naudojamos elektros gamybai. Tyrejai siekia sukurti naujos kartos efektyvesnes, patogesnes naudoti ir pasižyminčias labai žemu triukšmingumo lygiu vertikalios ašies vejjo elektrines. Vienas iš straipsnyje pristatyto tyrimo tikslų - analizuoti aktyvaus menčių posūkio valdymo sistemą eksperimentiniame stende su nuolatinių magnetų sinchroniniu varikliu (NMSV) ir sukurti testavimo programas, skirtas analitiškai įvertinti šios sistemos charakteristikas. Šiuolaikinès komercinès vertikalios ašies vejjo elektrinès neturi aktyvaus menčių posūkio valdymo sistemų, tačiau šio metodo koncepcija atveria naujas galimybes pagerinti vejjo elektrinių efektyvumą, saugą ir naudojimo patogumą. Tyrimas susideda iš matematinio modelio ir valdymo sistemos, veikiančios modeliavimo eksperimentiniame stende uždaroje sistemoje su aktyvaus menčių posūkio valdymo sistema. Naudojant specialiai sukurtą vertikalios ašies vèjo elektrinès modeli MATLAB Simulink programoje, aktyvaus menčiu posūkio valdymo sistema buvo analizuojama îvairiomis aplinkybėmis, artimomis realioms eksploatacinèms sąlygoms. Testavimo rezultatai parodè, kad aktyvaus menčių posūkio valdymo sistema su NMSV gali būti labai efektyvi, greita ir veikti užduotomis sąlygomis. Tyrimas atskleidè, kad naudojant NMSV ir siekiant geriausių rezultatų bei ekonominių rodiklių, reikia laikytis tam tikrų sąlygų. Visapusiškas ir efektyvus aktyvaus menčių posūkio valdymo sistemos naudojimas gali pagerinti vertikalios ašies vèjo elektrinių galios generavimo charakteristikas.

Raktažodžiai: vertikalios ašies vejjo elektrinès, menčių posūkio valdymas, nuolatinių magnetų sinchroninis variklis, vejo elektrinè, MATLAB 